\title{
Barite-Micromax mixture, an enhanced weighting agent for the elimination of barite sag in invert emulsion drilling fluids
}

\author{
Salem Basfar ${ }^{1} \cdot$ Abdelmjeed Mohamed $^{1} \cdot$ Salaheldin Elkatatny ${ }^{1}$
}

Received: 26 February 2020 / Accepted: 16 April 2020 / Published online: 24 April 2020

(c) The Author(s) 2020, corrected publication 2020

\begin{abstract}
Weighting agents are mixed with the drilling mud to provide the high density required to control high-pressure high-temperature (HPHT) wells throughout the drilling operation. Solids sag occurs when the weighting agent separates from the liquid phase and settles down, causing variations in the drilling fluid density. This study evaluates barite-manganese tetroxide (Micromax) mixture to eliminate solids sag issue encountered with weighted invert emulsion drilling fluids at HPHT conditions. Micromax additive was added to barite-weighted fluids in different concentrations, 0,15 , and $30 \mathrm{wt} \%$ of the total weighting agent. Static and dynamic sag tests were used to evaluate the sag tendency of the new formulation under static and dynamic conditions. The performance of the new formulation was evaluated by measuring the electrical stability, density, rheological, viscoelastic, and filtration properties of the drilling fluid. The obtained results showed that Micromax additive improves drilling fluid stability by reducing the sag tendency. Adding only $30 \mathrm{wt} \%$ of Micromax additive eliminated barite sag issue in both dynamic and static conditions at $350{ }^{\circ} \mathrm{F}$. $30 \mathrm{wt} \%$ Micromax increased the base fluid density by $5.4 \%$ and the yield point by $115 \%$ and maintained the gel strength value at $12 \mathrm{lb} / 100 \mathrm{ft}^{2}$, while it reduced the plastic viscosity by $30 \%$. The addition of Micromax additive improved the viscoelastic properties of the drilling fluid by maintaining a higher storage modulus to the loss modulus ratio when compared with the barite sample (in the range 4-4.5). Furthermore, 30 wt $\%$ Micromax improved the filtration performance by reducing the filtrate volume, filter cake weight, and filter cake thickness by $50 \%$.
\end{abstract}

Keywords Invert emulsion drilling fluid $\cdot$ Weighting agent $\cdot$ Micromax $\cdot$ Barite $\cdot$ Solids sag $\cdot$ HPHT wells

\section{Introduction}

Weighting agents are used to increase the density of the drilling fluid to efficiently control oil and gas well throughout the drilling operation (Caenn et al. 2011; Hossain and Al-Majed 2015; Stroud 1922, 1926). The common weighting agents used in drilling applications are calcium carbonate, barite, ilmenite, manganese tetroxide (Micromax), and hematite (Yao et al. 2014; Elkatatny et al. 2012a, b; Al-Yami et al. 2007; Tehrani et al. 2014). Because of the good properties and low cost, barite is the most widely used weighting

Salaheldin Elkatatny

elkatatny@kfupm.edu.sa

Salem Basfar

g201407960@kfupm.edu.sa

Abdelmjeed Mohamed

abdelmjeed.mohamed@kfupm.edu.sa

1 Department of Petroleum Engineering, King Fahd University of Petroleum and Minerals, Dhahran 31261, Saudi Arabia agent (Pozebon et al. 2005; Nguyen et al. 2009; Bageri et al. 2017). However, barite sag is a serious issue when using barite-weighted fluids. It occurs when solid particles separate from the liquid phase and settle down (Bern et al. 2000; Omland et al. 2007). Because of the solids settlement, the fluid density will vary, causing a severe well control issue (Saasen et al. 2002; Zamora and Bell 2004), and interference with the drilling operations (Mohamed et al. 2017). This phenomenon occurs in both directional and vertical wells, whether under dynamic or static conditions, most commonly with dynamic conditions at low shear rates (Murphy et al. 2008).

Many parameters affect the sagging phenomenon in drilling operations such as fluid type and density, drilling fluid additives, weighting agent, particle size, low shear rheology, downhole temperature, wellbore geometry and inclination, drill pipe rotation, and time (Bern et al. 2000). Several experimental studies were performed to simulate and measure the barite sag tendency in the laboratory under static and dynamic conditions. One of the common methods to 
evaluate the sag tendency of the drilling fluid is measuring the weight difference between the top and bottom of the fluid column using flow loops, sag cell setup, and viscometer sag show test (Hanson et al. 1990; Aldea et al. 2001; Saasen et al. 2002; Temple et al. 2004; Murphy et al. 2008; Alabdullatif et al. 2015; Davis et al. 2017; Basfar et al. 2018; Elkatatny 2018, 2019; Boyou et al. 2019; Mohamed et al. 2020). Another method of barite sag measurement is using the rheological and viscoelastic properties obtained by different rheometers and correlates the data with sag tendency (Chilingarian et al. 1983; Saasen et al. 1995; Power and Zamora 2003; Maxey 2007; Bern et al. 2010). Ultrasonic and nuclear magnetic resonance (NMR) techniques were also utilized to measure the sag tendency of the drilling fluid by detecting the density stratification using the sound velocity and the influence of the magnetic field, respectively (Omland et al. 2007). Another advancement in solids sag testing was recently introduced by Ofei et al. 2020. They used a cylindrical glass cell with multiple light scattering techniques to characterize the homogeneity and settling speed of the solid particles in the drilling fluid.

Several studies were conducted to solve solids sag phenomenon in oil- and water-based muds by training rig personnel (Scott et al. 2004), optimizing the rheological properties of the drilling fluid using anti-sagging agents and rheology modifiers (Temple et al. 2004; Davis et al. 2017; Basfar et al. 2018; Elkatatny 2018, 2019; Mohamed et al. 2020), reducing the particle size of the weighting agent (Mohamed et al. 2017; Boyou et al. 2019), replacing the weight material, or adding a combination of weight materials (Alabdullatif et al. 2015; Abdou et al. 2018; Basfar et al. 2019; Mohamed et al. 2019).

Because of the limited resources and high demand for barite, other alternatives to barite are needed to weight the drilling fluid for HPHT applications (Blomberg and Melberg 1984). Research studies were conducted on the use of ilmenite as an alternative weighting agent because of its high density $\left(4.7-4.79 \mathrm{~g} / \mathrm{cm}^{3}\right)$, availability, and acid solubility (Haaland et al. 1976; Tuntland et al. 1982; Elkatatny et al. 2012a, b; Xiao et al. 2013). However, ilmenite abrasiveness to drilling fluid equipment is a major issue (Xiao et al. 2013), and it could be mitigated by using ilmenite with small particles $(<45 \mu \mathrm{m})$; less than $3 \%$ of large particles (larger than $45 \mu \mathrm{m}$ ) should be used (Blomberg and Melberg 1984). Micromax additive is another alternative weighting agent to barite. It has a high specific gravity (4.8), and the fine particles of Micromax additive (about $1 \mu \mathrm{m}$ ) make the abrasiveness and sag tendency of Micromax additive less than that of barite (Mustapai 2011; Ma et al. 2019). Micromax additive is reservoir friendly and causes less formation damage compared with other weighting agents (Al-Muhailan et al. 2014).

To solve the barite sag issue and the high cost of Micromax additive, compared to barite, this study evaluates the mixture of barite and Micromax to provide the required density of invert emulsion muds to drill HPHT wells effectively. Hence, the effect of combined weighting agents on sag tendency and drilling fluid properties is evaluated.

\section{Materials and methods}

Different concentrations of Micromax additive ( 0,15 , and $30 \mathrm{wt} \%$ of the total weighting agent) were added to the barite-weighted fluid to prepare the drilling fluid samples using the description shown in Table 1. Diesel was used as a continuous phase, while water was the dispersed phase. Primary and secondary emulsifiers (INVERMUL ${ }^{\circledR}$ and EZ MUL ${ }^{\circledR}$ ) were used to create a stable water-in-oil emulsion. Lime was used to enhance emulsion stability by activating the fatty acid emulsifiers, while calcium chloride was used as a clay and shale inhibitor. The viscosity of the invert emulsion mud was maintained using an organophilic clay $\left(\right.$ GELTONE $\left.^{\circledR}\right)$. Calcium carbonate was used as a bridging agent, and the drilling fluid was weighted using barite and Micromax additive in different ratios. The mixing sequence of the additives is as listed in Table 1.

\section{Experimental procedure}

\section{Material characterization}

The weighting agents, barite and Micromax, were characterized by measuring the elemental composition, morphology, and particle size distribution (PSD) to understand the mechanisms of sagging behavior of the solid particles and how the sag tendency can be reduced with Micromaxweighted fluids. The elemental composition was determined

Table 1 Drilling fluid recipe in field units (1 bbl of mud)

\begin{tabular}{llll}
\hline Additive & Amount & $\begin{array}{l}\text { Weight } \\
\text { percentage } \\
(\mathrm{wt} \%)\end{array}$ & $\begin{array}{l}\text { Mixing } \\
\text { time } \\
(\mathrm{min})\end{array}$ \\
\hline Diesel & $0.48 \mathrm{bbl}$ & 13.93 & - \\
INVERMUL $^{\circledR}$ & $8 \mathrm{lb}$ & 0.799 & 10 \\
Lime $^{\text {DURATONE }}{ }^{\circledR}$ & $6 \mathrm{lb}$ & 0.599 & 10 \\
Water $_{\text {Calcium chloride }}$ & $4 \mathrm{lb}$ & 0.4 & 10 \\
GELTONE $^{\circledR}$ & $0.053 \mathrm{bbl}$ & 1.85 & 10 \\
EZ MUL $^{\circledR}$ & $7 \mathrm{lb}$ & 0.699 & 10 \\
Calcium carbonate (fine) & $5 \mathrm{lb}$ & 0.5 & 20 \\
Calcium carbonate (medium) & $3 \mathrm{lb}$ & 0.3 & 10 \\
Weighting agent (Barite-Micro- & $500 \mathrm{lb}$ & 79.9 & 10 \\
max) & & 0.5 & 20 \\
\hline
\end{tabular}




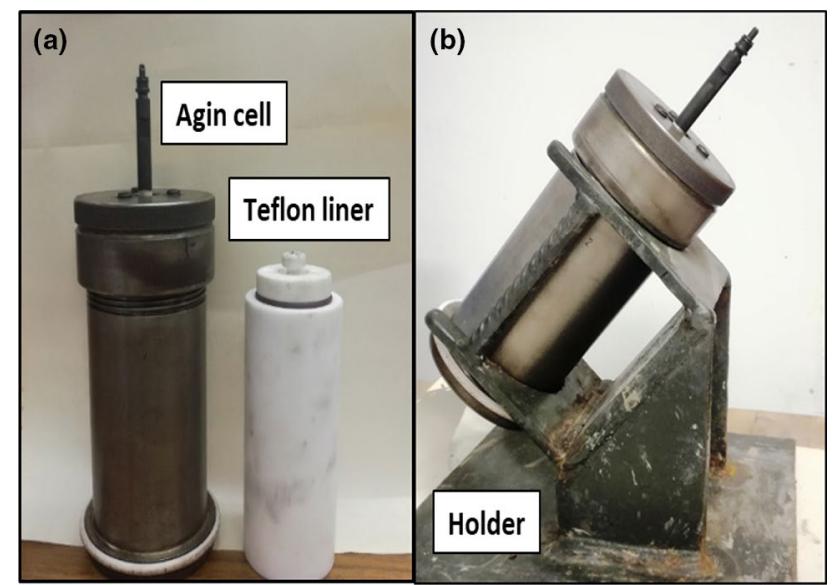

Fig. 1 Apparatus for static sag test: a vertical and $\mathbf{b}$ inclined $\left(45^{\circ}\right)$ (Elkatatny 2019)

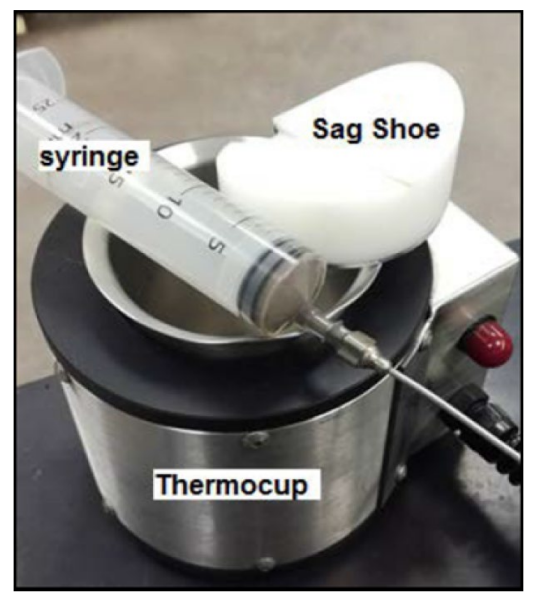

Fig. 2 Apparatus for dynamic sag test (Basfar et al. 2018)

by a small-spot X-ray fluorescence technique (micro-XRF) using the M4 TORNADO instrument. Scanning electron microscopy (SEM) was performed using the JEOL JSM5900LV instrument to determine the morphology of the weighting agents' particles, while TURBO TRAC particle size analyzer that uses laser diffraction method was utilized to determine the particle size distribution of the weighting agents used in this study.

\section{Sag tests}

Sag tests, static and dynamic, were used to study the sag tendency of fluid samples to determine the optimum concentration of Micromax additive. The static sag test was carried out for $24 \mathrm{~h}$ under vertical and inclined $\left(45^{\circ}\right)$ conditions at $350{ }^{\circ} \mathrm{F}$ and 500 psi, using an aging cell setup, Fig. 1, while the dynamic sag test was performed using viscometer sag shoe test, VSST, Fig. 2, at the standard conditions (30 min, $120^{\circ} \mathrm{F}$, and atmospheric pressure). The fluid samples are kept at testing conditions, and with time and due to the high temperature, the drilling fluid starts to degrade, and solid particles tend to separate and settle down due to the gravity effect. The main principle of the sag test is to measure the weight difference between the top and bottom of the fluid column after the test. The detailed procedure of the static and dynamic sag tests is well explained in the literature (Mohamed et al. 2017, 2019; Basfar et al. 2018, 2019).

\section{Rheological and viscoelastic properties}

The impact of adding Micromax additive on the rheological and viscoelastic properties of the mud was studied at $350^{\circ} \mathrm{F}$ by measuring plastic viscosity, yield point, gel strength, and the storage and loss modulus. Rheological properties were measured using OFITE 77-HPHT Viscometer. Yield point (YP) and plastic viscosity (PV) were obtained from the viscometer dial reading ( $\varnothing)$ at 300 and 600 RPM using Eqs. 1 and 2, while gel strength values were obtained from the direct dial reading at $3 \mathrm{RPM}$ after $10 \mathrm{~s}, 10 \mathrm{~min}$, and $30 \mathrm{~min}$ of static gel time. Storage modulus $\left(G^{\prime}\right)$ and loss modulus $\left(G^{\prime \prime}\right)$ were obtained from the frequency and amplitude oscillatory tests conducted using Anton Paar rheometer. Firstly, the amplitude sweep test was conducted to identify the linear viscoelastic range. The test was run at a constant frequency of $10 \mathrm{rad} / \mathrm{s}$ while the amplitude of the shear stress was increased gradually. Then, the frequency sweep test was run, using a fresh fluid sample, at a constant strain of 0.1 that falls within the linear viscoelastic range, and the storage modulus $G^{\prime}$ and loss modulus $G^{\prime \prime}$ were obtained at different angular frequencies. Both rheology and oscillatory tests were conducted at $2000 \mathrm{psi}$ and $350^{\circ} \mathrm{F}$.

$\mathrm{PV}(\mathrm{cP})=\emptyset_{600}-\emptyset_{300}$

$\mathrm{YP}\left(\frac{\mathrm{lb}}{100 \mathrm{ft}^{2}}\right)=\emptyset_{300}-\mathrm{PV}$

\section{Density and electrical stability}

The density and electrical stability of the invert emulsion mud were measured to study the effect of Micromax additive on these properties. The measurements were taken at ambient temperature using a mud balance and electrical stability tester.

\section{HPHT filtration}

The impact of using Micromax additive on the filtration properties of the drilling mud was evaluated using the HPHT filtration test. The test was conducted at 500 psi differential

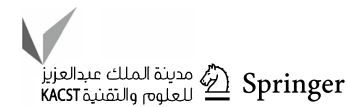


pressure and $350{ }^{\circ} \mathrm{F}$ using a ceramic filter disk with a mean pore diameter of $50 \mu \mathrm{m}$ as a filtration medium. The experiment was run for the standard test duration, $30 \mathrm{~min}$. The measured filtration properties are filter cake weight, filter cake thickness, and total filtrate volume.

\section{Results and discussion}

\section{Material characterization}

Weighting agents, barite and Micromax, were characterized by measuring the elemental composition using X-ray fluorescence, XRF. The results in Table 2 show that barite mainly contains $77.5 \mathrm{wt} \%$ barium, $17.7 \mathrm{wt} \%$ sulfur, and small traces of silicon, iron, and potassium. While Micromax additive contains $99.2 \mathrm{wt} \%$ manganese, the remaining weight is small traces of aluminum, silicon, calcium, and potassium. SEM images show that barite has heterogeneous particles with irregular shapes and sharp edges, while the particles of Micromax additive are uniform with a spherical shape, which makes the abrasiveness of Micromax additive less than that of barite, Fig. 3. The barite sample has large

Table 2 Elemental composition of weighting agents using XRF

\begin{tabular}{lll}
\hline Element & \multicolumn{2}{l}{ Mass percent (\%) } \\
\cline { 2 - 3 } & Barite & Micromax \\
\hline $\mathrm{Ba}$ & 77.5 & - \\
$\mathrm{S}$ & 17.7 & - \\
$\mathrm{Mn}$ & - & 99.2 \\
$\mathrm{~K}$ & 0.6 & 0.2 \\
$\mathrm{Ca}$ & - & 0.05 \\
$\mathrm{Al}$ & - & 0.5 \\
$\mathrm{Si}$ & 2.8 & 0.05 \\
$\mathrm{Fe}$ & 1.4 & - \\
\hline
\end{tabular}

particles, and the average particle size was $18 \mu \mathrm{m}$, while Micromax additive has fine particles with an average particle size of around $1.7 \mu \mathrm{m}$, Fig. 4. The fine uniform particles of Micromax additive result in a strong Brownian motion allowing the particles to create random collisions that consequently reduce the gravity effect on the solid particles and enhance the sag performance of the drilling fluid (Wen et al. 2009; Ma et al. 2019).

\section{Sag tests}

After preparing the fluid samples, using different ratios of barite and Micromax additive, the sag tendency of these samples was studied under static and dynamic conditions, Fig. 5. The base mud sample, $100 \mathrm{wt} \%$ barite, revealed a high sag tendency under both conditions with a dynamic sag factor (VSST) of 1.3 and a sag factor of around 0.6. The addition of Micromax additive improved the stability of the mud and reduced the sag factor and the VSST, and as the concentration of Micromax additive was increased, the sag factor reduced. Only $30 \mathrm{wt} \%$ of Micromax additive was sufficient to bring the sag factor and VSST values to the acceptable range, $0.5-0.53$ and $0-1.0$, respectively (Aldea et al. 2001; Maxey 2007; Alabdullatif et al. 2015). Consequently, solids sag issue will not be encountered, and drilling with this fluid formulation would be safe.

Many factors contributed to the improvement in solids suspension capability when adding Micromax additive to the drilling fluid formulations. Firstly, the strong Brownian motion of the fine, spherical, and uniform particles of Micromax additive allows the solid particles to make random collisions and reduces the gravity effect on the solid particles (Ma et al. 2019). Secondly, the particles of Micromax additive have a higher surface area-to-volume ratio compared to barite that makes the lift and drag forces greater than the cohesion and gravity forces (Boyou et al. 2019). Thirdly,

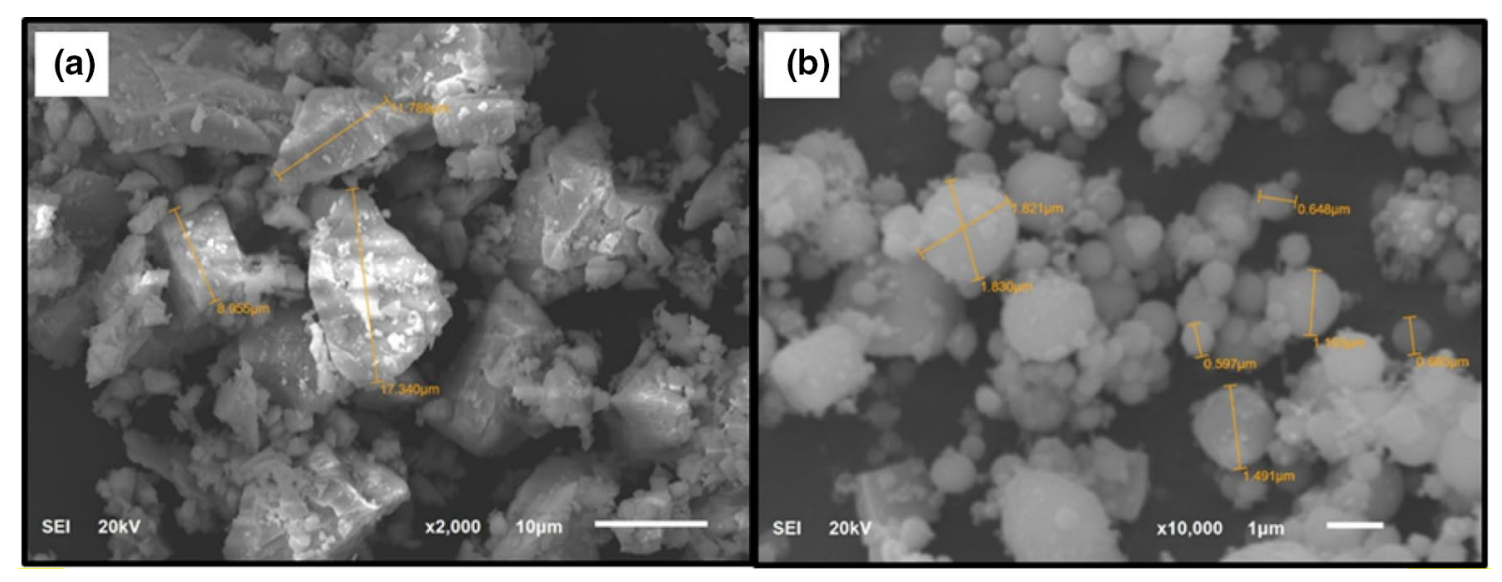

Fig. 3 Morphology of the weighting agents using SEM: a Barite and b Micromax additive 
Fig. 4 PSD of the weighting agents

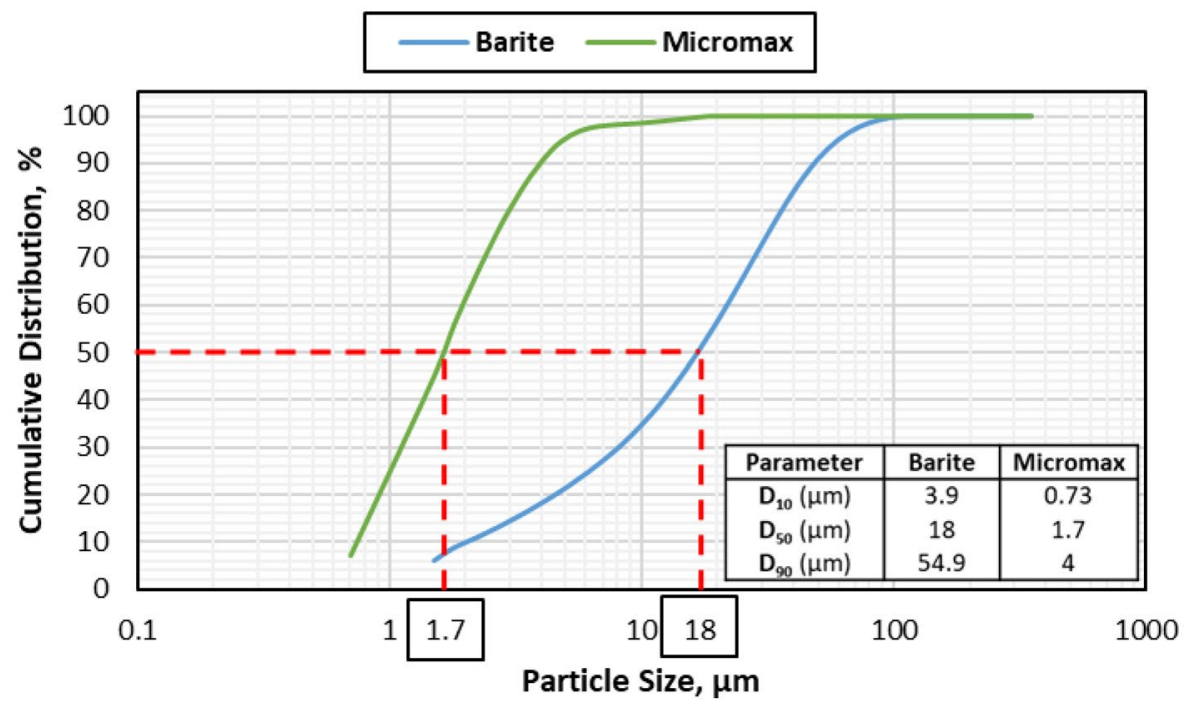

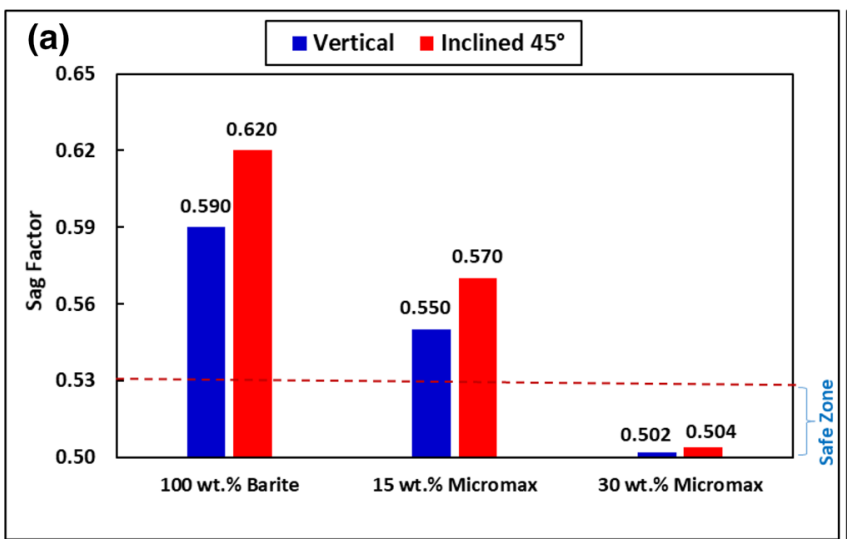

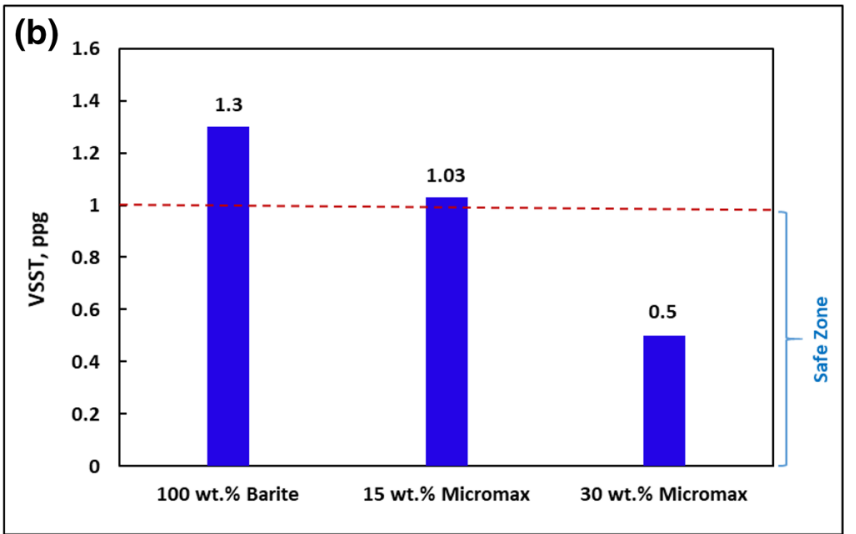

Fig. 5 Effect of Micromax additive on sag tendency: $\mathbf{a}$ at static conditions, $350^{\circ} \mathrm{F}$, and $\mathbf{b}$ at dynamic conditions, $120^{\circ} \mathrm{F}$

Micromax additive has a higher surface charge than barite, and as the surface charge increases, the stability of the colloidal system increases (Mohamed et al. 2019; Joseph and Singhvi 2019). Moreover, additional enhancement in the sag tendency will be observed in real cases because the high density of Micromax additive reduces the total amount of the weighting agent required to formulate a drilling fluid with the same weight of the base fluid, and thus, it reduces the solids loading in the drilling fluid.

\section{Rheological and viscoelastic properties}

The impact of Micromax additive on the rheological and viscoelastic properties of the fluid samples was investigated at $350{ }^{\circ} \mathrm{F}$. The flow curves (shear stress vs. shear rate) of the drilling fluid samples are presented in Fig. 6. As shown in Fig. 6, all the drilling fluid samples behave as nonNewtonian fluids and fit the Bingham plastic model with an $R$-squared of 0.98 . As the concentration of Micromax

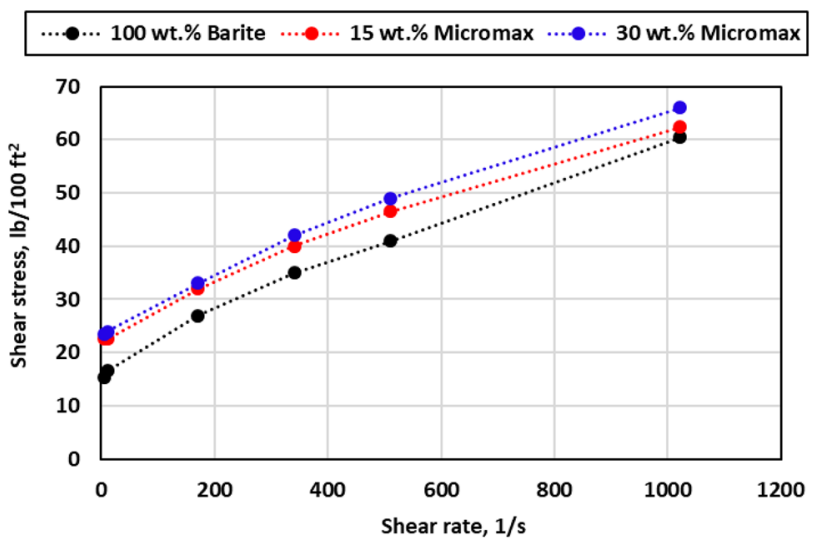

Fig. 6 Flow curves for the drilling fluid samples $\left(350{ }^{\circ} \mathrm{F}\right)$

additive increased, it resulted in higher shear stress values. Figure 7 shows that increasing the concentration of Micromax additive from 0 to $30 \mathrm{wt} \%$ increased the yield point 

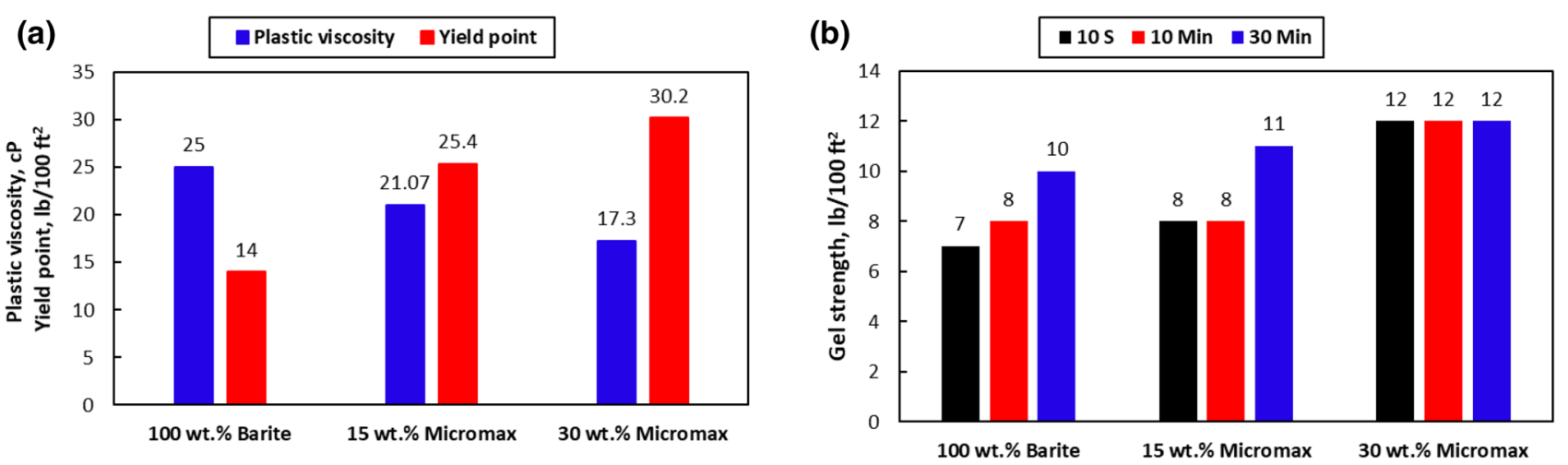

Fig. 7 Effect of Micromax additive on a yield point and plastic viscosity and $\mathbf{b}$ gel strength $\left(350{ }^{\circ} \mathrm{F}\right)$

of the drilling fluid from 14 to $30.2 \mathrm{lb} / 100 \mathrm{ft}^{2}$ and slightly reduced the plastic viscosity from 25 to $17.3 \mathrm{cP}$. Consequently, the increase in the yield point and the decrease in the plastic viscosity increased the YP/PV ratio from 0.56 to 1.75 . The $\mathrm{YP} / \mathrm{PV}$ ratio is a very important parameter in drilling fluid design. It affects the drilling fluid performance and controls several drilling parameters such as mud stability, hole cleaning, equivalent circulating density, and surge and swap pressures (Chilingarian et al. 1983; Power and Zamora 2003). The yield point indicates the drilling fluid's ability to suspend the solid particles during circulation. The enhancement of yield point confirms the sag test results that adding Micromax additive improves the suspension capability of the mud; however, increasing the YP/PV ratio more than required would result in mud coagulation (Chilingarian et al. 1983). Conversely, the drilling fluid with high plastic viscosity values requires more pumping pressure because of the additional frictional pressure; therefore, adding Micromax additive to barite-weighted fluids would result in less frictional pressure.

Moreover, adding Micromax additive improved the gel strength of barite-weighted fluids. The gel strength indicates the drilling fluid's ability to suspend the solid particles when there is no circulation. For 0 and $15 \mathrm{wt} \%$ Micromax samples, the gel strength showed a slight increase with time while the drilling fluid sample with $30 \mathrm{wt} \%$ Micromax exhibited a flat rheology behavior with a constant gel strength value with time $\left(12 \mathrm{lb} / 100 \mathrm{ft}^{2}\right)$ indicating quick and more stable gel structure (Fig. 7b). Consequently, solid particles settlement is less likely to occur under that condition. Figure 8 compares the viscoelastic properties of the drilling fluid samples. As shown in Fig. 8a, all the drilling fluid samples showed a linear viscoelastic range below $0.6 \%$ strain where the storage modulus $\left(G^{\prime}\right)$ was greater than the loss modulus $\left(G^{\prime \prime}\right)$; thus, the suspensions behave more like viscoelastic solids with a stable gel structure. Form Fig. 8b, increasing the concentration of Micromax additive to $30 \mathrm{wt} \%$ resulted in higher ratios of $G^{\prime} / G^{\prime \prime \prime}$ than the other samples. This increase in $G^{\prime} / G^{\prime \prime}$ ratio indicates a stronger gel structure confirming the gel strength and sag test results (Bui et al. 2012).
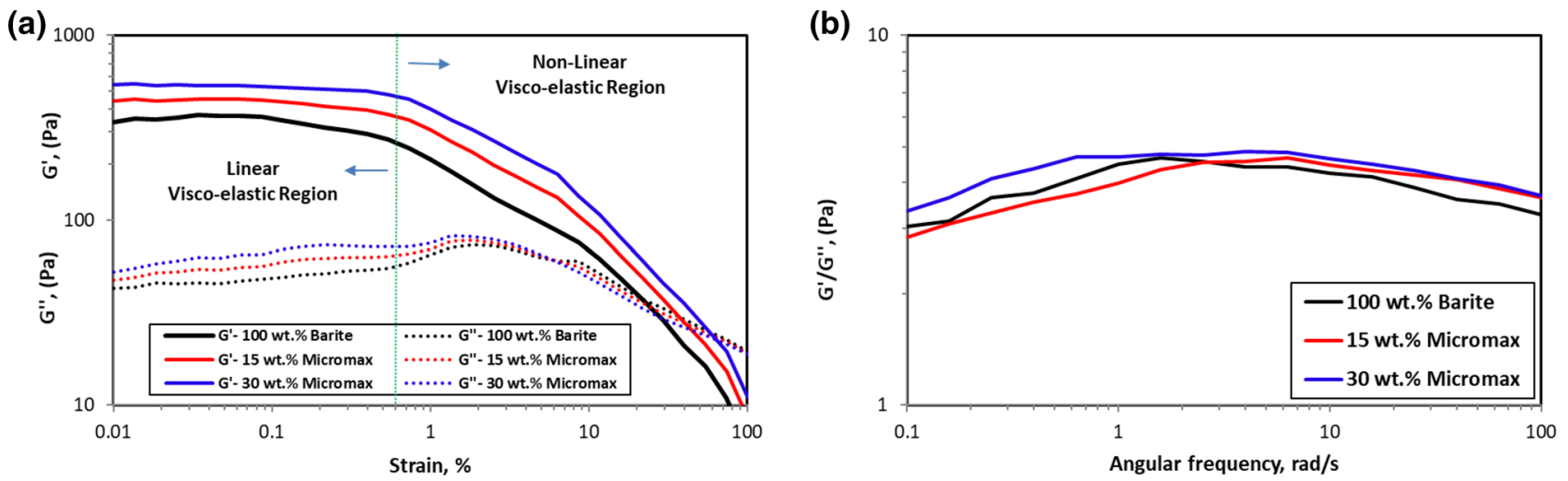

Fig. 8 Effect of Micromax additive on viscoelastic properties a amplitude sweep test and $\mathbf{b}$ frequency sweep test $\left(350{ }^{\circ} \mathrm{F}\right)$ 
Table 3 Summary of the drilling fluid properties

\begin{tabular}{llll}
\hline Parameter & $100 \mathrm{wt} \%$ Barite & $15 \mathrm{wt} \%$ Micromax & $30 \mathrm{wt} \%$ Micromax \\
\hline Density (ppg) & 20.4 & 21.3 & 21.5 \\
Electrical stability (V) & 1334 & 1250 & 1140 \\
Yield point $\left(\mathrm{lb} / 100 \mathrm{ft}^{2}\right)$ & 14 & 25.4 & 30.2 \\
Plastic viscosity $(\mathrm{cP})$ & 25 & 21.07 & 17.3 \\
YP/PV & 0.56 & 1.2 & 1.75 \\
Gel strength & $7 / 8 / 10$ & $8 / 8 / 11$ & $12 / 12 / 12$ \\
$\quad\left(10\right.$ s/10 min/30 min), lb/100 $\mathrm{ft}^{2}$ & & & 1.2 \\
Filtrate volume $\left(\mathrm{cm}^{3}\right)$ & 2.6 & 2.1 & 1.27 \\
Filter cake thickness $(\mathrm{mm})$ & 3.30 & 2.54 & 14 \\
Filter cake weight $(\mathrm{g})$ & 32.3 & 26.53 &
\end{tabular}

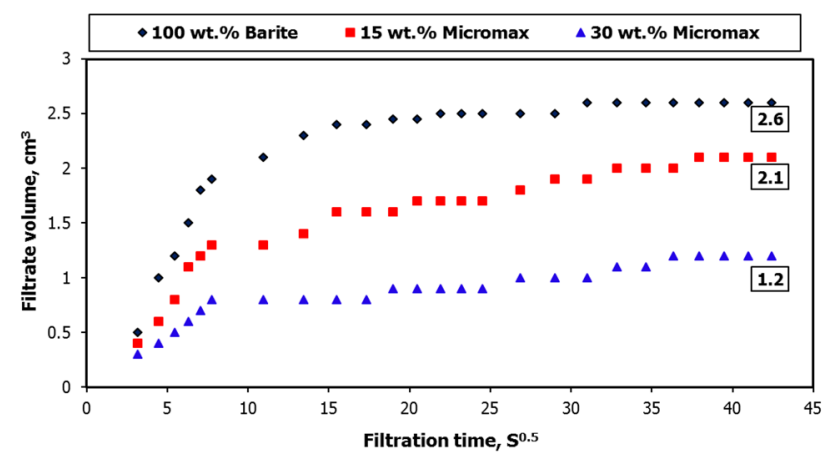

Fig. 9 Effect of Micromax additive on the filtration performance of the drilling mud $\left(350{ }^{\circ} \mathrm{F}\right)$

\section{Density and electrical stability}

The base fluid sample has a density of 20.4 ppg and electrical stability of $1334 \mathrm{~V}$. Adding Micromax additive to the base fluid sample increased the density of the drilling mud to reach up to $21.5 \mathrm{ppg}$ with $30 \mathrm{wt} \%$ Micromax sample, Table 3. The increase in fluid density is attributed to the high density of Micromax additive $\left(4.8 \mathrm{~g} / \mathrm{cm}^{3}\right)$ compared to that of barite $\left(4.2-4.4 \mathrm{~g} / \mathrm{cm}^{3}\right)$; therefore, less solid content will be required to provide the same density (Caenn et al. 2011; Al-Muhailan et al. 2014; Mustapai 2011). Conversely, increasing the concentration of Micromax additive up to $30 \mathrm{wt} \%$ slightly decreased the electrical stability to $1140 \mathrm{~V}$ because of the difference in electrical conductivity and surface charge, between Micromax additive and barite. This decrease is not significant because the electrical stability is still far above the acceptable value in drilling practices, $500 \mathrm{~V}$ (Van Zanten et al. 2012).

\section{Filtration properties}

The filtration performance of drilling fluid samples was studied at $350{ }^{\circ} \mathrm{F}$ and 500 psi. As shown in Fig. 9 and Table 3, adding Micromax additive enhanced the filtration performance of the drilling fluid. When the concentration of Micromax additive was increased from 0 to $30 \mathrm{wt} \%$, the total filtrate volume, filter cake thickness, and filter cake weight were reduced by approximately $50 \%$. The filtrate volume was decreased from 2.6 to $1.2 \mathrm{~cm}^{3}$, the filter cake thickness was decreased from 2.9 to $1.9 \mathrm{~mm}$, and the filter cake weight was reduced from 32.4 to $14 \mathrm{~g}$. The fine and uniform particles of Micromax additive improved the bridging effect of the solid particles resulting in a thinner and more packed filter cake, Fig. 10 (Ma et al. 2019). The less filtrate volume, filter cake weight, and filter cake thickness, the better the filtration performance, and the less damage caused to the drilled formation. Moreover, the thinner the filter cake, the less possibility of stuck pipe will be encountered during the drilling operation.
Fig. 10 Formed filter cake: a $100 \mathrm{wt} \%$ barite, $\mathbf{b} 15 \mathrm{wt} \%$ Micromax and c $30 \mathrm{wt} \%$ Micro$\max \left(350^{\circ} \mathrm{F}\right)$

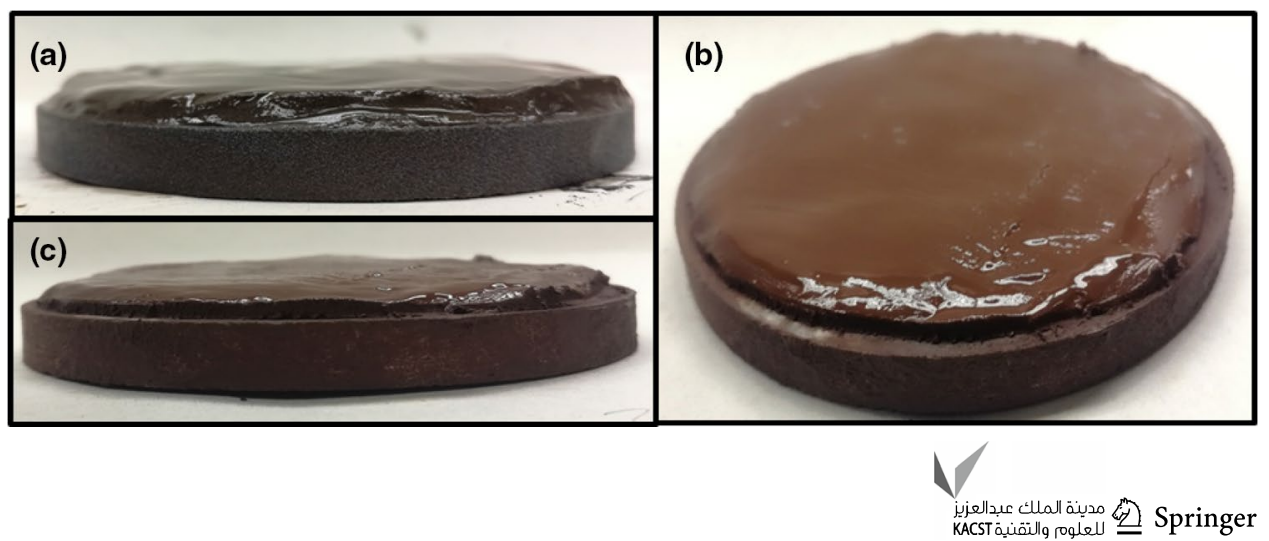




\section{Summary and conclusion}

In summary, the addition of Micromax additive to bariteweighted drilling fluid was found effective in reducing sag tendency at HPHT conditions. The addition of Micromax additive increased the fluid density and slightly reduced the electrical stability of the invert emulsion mud within the acceptable range. Micromax additive improved the rheological, viscoelastic, and filtration properties of the drilling fluid. $30 \mathrm{wt} \%$ Micromax increased the yield point by $115 \%$ and maintained the gel strength value at $12 \mathrm{lb} / 100 \mathrm{ft}^{2}$, while it reduced the plastic viscosity by $30 \%$. The filtrate volume, filter cake thickness, and filter cake weight were significantly reduced by $50 \%$; thus, less formation damage from the fluid filtrate invasion is anticipated. $30 \mathrm{wt} \%$, of the total weighting agent, was found to be the optimum concentration of Micromax additive because it was enough to eliminate barite sag under dynamic and static conditions and yielded the optimum drilling fluid properties. With this fluid formulation and testing conditions, adding more concentration is not required, and it would add additional cost to the drilling operations.

Acknowledgements : The authors wish to acknowledge King Fahd University of Petroleum and Minerals (KFUPM) for utilizing the various facilities in carrying out this research.

Open Access This article is licensed under a Creative Commons Attribution 4.0 International License, which permits use, sharing, adaptation, distribution and reproduction in any medium or format, as long as you give appropriate credit to the original author(s) and the source, provide a link to the Creative Commons licence, and indicate if changes were made. The images or other third party material in this article are included in the article's Creative Commons licence, unless indicated otherwise in a credit line to the material. If material is not included in the article's Creative Commons licence and your intended use is not permitted by statutory regulation or exceeds the permitted use, you will need to obtain permission directly from the copyright holder. To view a copy of this licence, visit http://creativecommons.org/licenses/by/4.0/.

\section{References}

Abdou MI, Al-Sabagh AM, Ahmed HES, Fadl AM (2018) Impact of barite and ilmenite mixture on enhancing the drilling mud weight. Egypt J Pet 27(4):955-967. https://doi.org/10.1016/j. ejpe.2018.02.004

Alabdullatif ZA, Al-yami AS, Wagle VB, Bubshait AS, Al-Safran AM (2015) Development of new kill fluids with minimum sagging problems for high-pressure Jilh Formation in Saudi Arabia. Society of Petroleum Engineers. https://doi.org/10.2118/171683-MS

Aldea C, Growcock FB, Lee LJ, Friedheim JE, Oort EV (2001) Prevention of dynamic sag in deepwater invert emulsion fluids. In: Proceedings of the AADE national drilling conference, 'drilling technology,' Houston, Texas, USA, 27-29 March. AADE-01-NCHO-51
Al-Muhailan M, Al-Foudari SJ, Debroy A, Rajagopalan A (2014) Achievement of maximum mud weights in K-formate WBM with Micromax and its successful implementations in deep HPHT wells. In: Proceedings of the IADC/SPE Asia Pacific drilling technology conference, Bangkok, Thailand, 25-27 August. IADC/ SPE-170472-MS. https://doi.org/10.2118/170472-MS

Al-Yami AS, Nasr-El-Din HA, Al-Majed AA, Menouar H (2007) An innovative manganese tetra-oxide/ $\mathrm{KCl}$ water-based drill-in fluids for HT/HP wells. In: Proceedings of the SPE annual technical conference and exhibition, Anaheim, California, USA, 11-14 November. SPE-110638-MS. https://doi.org/10.2118/110638-MS

Ba Geri BS, Mahmoud M, Abdulraheem A, Al-Mutairi SH, Elkatatny SM, Shawabkeh RA (2017) Single stage filter cake removal of barite weighted water based drilling fluid. J Pet Sci Eng 149:476484. https://doi.org/10.1016/j.petrol.2016.10.059

Basfar S, Elkatatny S, Mahmoud M, Kamal MS, Murtaza M, Stanitzek T (2018) Prevention of barite sagging while drilling highpressure high-temperature (HPHT) wells. In: Proceedings of the SPE Kingdom of Saudi Arabia annual technical symposium and exhibition, Dammam, Saudi Arabia, 23-26 April. SPE192198-MS. https://doi.org/10.2118/192198-MS

Basfar S, Mohamed A, Elkatatny S, Al-Majed AA (2019) Combined barite-ilmenite weighting material to prevent barite sag in water-based drilling fluid. Materials 12(12):1-13. https://doi. org/10.3390/ma12121945

Bern PA, Oort EV, Neustadt B, Ebeltoft H, Zurdo C, Zamora M, Slater KS (2000) Barite sag: measurement, modeling, and management. SPE Drill Complet 15(1):25-30. https://doi. org/10.2118/62051-PA

Bern PA, Zamora M, Hemphill AT, Marshall D, Omland TH, Morton EK (2010) Field monitoring of weight-material sag

Blomberg NE, Melberg B (1984) Evaluation of ilmenite as weight material in drilling fluids. J Pet Technol 36(06):969-974. https ://doi.org/10.2118/11085-PA

Boyou NV, Ismail I, Sulaiman WRW, Haddad AS, Husein N, Hui HT, Nadaraja K (2019) Experimental investigation of hole cleaning in directional drilling by using nano-enhanced water-based drilling fluids. J Pet Sci Eng 176:220-231. https://doi.org/10.1016/j. petrol.2019.01.063

Bui B, Saasen A, Maxey J, Ozbayoglu ME, Miska SZ, Yu M, Takach NE (2012) Viscoelastic properties of oil-based drilling fluids. Annu Trans Nordic Soc 20(2012):33-47

Caenn R, Darley HCH, Gray GR (2011) Composition and properties of drilling and completion fluids. 6th ed. Elsevier. ISBN 9780123838582

Chilingarian G, Alp E, Uslu S, Gonzales S, Ronald J (1983) Drilling fluid evaluation using yield point-plastic viscosity correlation. Paper SPE-12469-MS

Davis L, Lfvanec W, Shumway W (2017) Additive to enhance sag stability of drilling fluid. WO Patent WO2017/188946 Al

Elkatatny S (2018) Enhancing the stability of invert emulsion drilling fluid for drilling in high-pressure high-temperature conditions. Energies 11(9):2393. https://doi.org/10.3390/en11092393

Elkatatny S (2019) Mitigation of barite sagging during the drilling of high-pressure high-temperature wells using an invert emulsion drilling fluid. Powder Technol 352:325-330. https://doi. org/10.1016/j.powtec.2019.04.037

Elkatatny S, Al Moajil A, Nasr-El-Din HA (2012a) Evaluation of a new environmentally friendly treatment to remove $\mathrm{Mn3O} 4$ filter cake. In: Proceedings of the IADC/SPE Asia Pacific drilling technology conference (APDT), Tianjin, China, 9-11 July. SPE-156451-MS. https://doi.org/10.2118/156451-MS

Elkatatny S, Nasr-El-Din H, Al-Bagoury M (2012b) Evaluation of micronized ilmenite as weighting material in water-based drilling fluids for HPHT applications. In: Proceedings of the SPE Kuwait international petroleum conference and exhibition, 
Kuwait City, Kuwait, 10-12 December. SPE-163377-MS. https ://doi.org/10.2118/163377-MS

Haaland E, Pettersen G, Tuntland OB (1976) Testing of iron oxides as weight materials for drilling muds. SPE-6218-MS

Hanson PM, Trigg TK, Rachal G, Zamora M (1990) Investigation of barite "sag" in weighted drilling fluids in highly deviated wells. In: Proceedings of the SPE annual technical conference and exhibition, New Orleans, Louisiana, USA, 23-26 September. SPE-20423-MS. https://doi.org/10.2118/20423-MS

Hossain M, Al-Majed AA (2015) Fundamentals of sustainable drilling engineering. Wiley, New York. ISBN 9780470878170

Joseph E, Singhvi G (2019) Multifunctional nanocrystals for cancer therapy: a potential nanocarrier. In: Grumezescu AM (ed) Nanomaterials for drug delivery and therapy. William Andrew Publishing, Burlington, pp 91-116. https://doi.org/10.1016/ B978-0-12-816505-8.00007-2

Ma J, Yu P, Xia B, An Y (2019) Micro-manganese as a weight agent for improving the suspension capability of drilling fluid and the study of its mechanism. RSC Adv 9(61):35509-35523. https:// doi.org/10.1039/C9RA07283G

Maxey J (2007) Rheological analysis of static and dynamic sag in drilling fluids. Annu Trans Nordic Rheol Soc 15:181-188

Mohamed AK, Elkatatny SA, Mahmoud MA, Shawabkeh RA, AlMajed AA (2017) The evaluation of micronized barite as a weighting material for completing HPHT wells. In: Proceedings of the SPE middle east oil and gas show and conference, Manama, Kingdom of Bahrain, 6-9 March. SPE-183768-MS. https://doi. org/10.2118/183768-MS

Mohamed A, Basfar S, Elkatatny S, Al-Majed A (2019) Prevention of barite sag in oil-based drilling fluids using a mixture of barite and ilmenite as weighting material. Sustainability 11(20):5617. https ://doi.org/10.3390/su11205617

Mohamed A, Al-Afnan S, Elkatatny S, Hussein I (2020) Prevention of barite sag in water-based drilling fluids by a urea-based additive for drilling deep formations. Sustainability 12(7):2719. https:// doi.org/10.3390/su12072719

Murphy RJ, Jamison DE, Hemphill T, Bell SA, Albrecht CE (2008) Measuring and predicting dynamic sag. SPE Drill Complet 23(02):142-149. https://doi.org/10.2118/103088-PA

Mustapai H (2011) The performance of Micromax as an alternatives weighting material in high density synthetic based Mud. MS thesis, Universiti Teknologi PETRONAS

Nguyen T, Miska S, Yu M, Takach N (2009) Predicting dynamic barite sag in newtonian-oil based drilling fluids. In: Proceedings of the SPE annual technical conference and exhibition, New Orleans, Louisiana, USA, 4-7 October. SPE-124137-MS. https://doi. org/10.2118/124137-MS

Ofei TN, Lund B, Saasen A, Sangesland S, Linga H, Gyland KR, Kawaji M (2020) Barite sag measurements. In: Proceedings of the IADC/SPE international drilling conference and exhibition, Galveston, Texas, USA, 3-5 March. SPE-199567-MS. https://doi. org/10.2118/199567-MS

Omland TH, Saasen A, Zwaag C, Amundsen PA (2007) The effect of weighting material sag on drilling operation efficiency. In: Proceedings of the SPE Asia Pacific oil and gas conference and exhibition, Jakarta, Indonesia, 30 October-1 November. SPE110537-MS. https://doi.org/10.2118/110537-MS

Power D, Zamora M (2003) Drilling fluid yield stress: measurement techniques for improved understanding of critical drilling fluid parameters. In: Proceedings of the AADE national technology conference, Houston, Texas, USA, 1-3 April. AADE-03-NTCE-35

Pozebon D, Lima EC, Maia SM, Fachel JM (2005) Heavy metals contribution of non-aqueous fluids used in offshore oil drilling. Fuel 84(1):53-61. https://doi.org/10.1016/j.fuel.2004.08.002

Saasen A, Liu D, Marken CD (1995) Prediction of barite sag potential of drilling fluids from rheological measurements. In: Proceedings of the SPE/IADC drilling conference, Amsterdam, The Netherlands, 28 February-2 March. SPE-29410-MS. https://doi. org/10.2523/29410-ms

Saasen A, Jordal OH, Burkhead D, Berg PC, Løklingholm G, Pedersen ES, Turner J, Harris MJ (2002) Drilling HT/HP wells using a cesium formate based drilling fluid. In; Proceedings of the IADC/ SPE drilling conference, Dallas, Texas, USA, 26-28 February. IADC/SPE-74541-MS. https://doi.org/10.2118/74541-MS

Scott PD, Zamora M, Aldea C (2004) Barite-sag management: challenges, strategies, opportunities. In: Proceedings of the IADC/ SPE drilling conference, Dallas, Texas, USA, 2-4 March. IADC/ SPE-87136-MS. https://doi.org/10.2118/87136-MS

Stroud BK (1922) Mud laden fluids and tables on specific gravities and collapsing pressures. Department of Conservation

Stroud BK (1926) Application of mud-laden fluids to oil or gas wells. US patent US1575945 A

Tehrani A, Cliffe A, Hodder MH, Young S, Lee J, Stark J, Seale S (2014) Alternative drilling fluid weighting agents: a comprehensive study on ilmenite and hematite. In: Proceedings of the IADC/SPE drilling conference and exhibition, Fort Worth, Texas, USA, 4-6 March. IADC/SPE-167937-MS. https://doi. org/10.2118/167937-MS

Temple C, Paterson F, Leith D (2004) Method for reducing sag in drilling, completion, and workover fluids. WO Patent WO2004/113467 A1

Tuntland OB, Herford HJ, Lehne KA, Haaland E (1982) Iron oxide as weight materials for drilling muds. Erdoel/Erdgas Z 97:300-302

Van Zanten R, Miller JJ, Baker C (2012) Improved stability of invert emulsion fluids. In Proceedings of the IADC/SPE drilling conference and exhibition, San Diego, California, 6-8 March. IADC/ SPE-151404-MS. https://doi.org/10.2118/151404-MS

Wen D, Lin G, Vafaei S, Zhang K (2009) Review of nanofluids for heat transfer applications. Particuology 7(2):141-150. https://doi. org/10.1016/j.partic.2009.01.007

Xiao J, Nasr-El-Din HA, Al-Bagoury M (2013) Evaluation of micronized ilmenite as a weighting material in oil-based drilling fluids for HPHT applications. In: Proceedings of the SPE European formation damage conference and exhibition, Noordwijk, The Netherlands, 5-7 June. SPE-165184-MS. https://doi. org/10.2118/165184-MS

Yao R, Jiang G, Li W, Deng T, Zhang H (2014) Effect of water-based drilling fluid components on filter cake structure. Powder Technol 262:51-61. https://doi.org/10.1016/j.powtec.2014.04.060

Zamora M, Bell R (2004) Improved wellsite test for monitoring barite sag. In: Proceedings of the AADE drilling fluids conference, Houston, Texas, USA, 6-7 April 2004. AADE-04-DFHO-19

Publisher's Note Springer Nature remains neutral with regard to jurisdictional claims in published maps and institutional affiliations. 